\title{
Review of Financial Inclusion Practice and its Success in India
}

\author{
Dr. Satish K Mittal, and Ms. Shuchi Shukla \\ Gautam Buddha University
}

\begin{abstract}
Financial inclusion is a systematic effort to provide essential financial services to all and especially to poor people. This concept has been pushed up by government of India and RBI because even after so many years of independence high population of India remain unbanked because high population of India lives in rural area and poor people and they are not literate enough to understand the pros and cons of various essential financial services. In this paper efforts are made to review various schemes initiated by Government, RBI and others to promote financial inclusion. A model has been designed in this paper to explore various dimensions of financial inclusion. Financial inclusion has increased in overall in India but its effectiveness is still doubted.
\end{abstract}

\section{Introduction}

Financial Inclusion (FI) is a formulated process of providing financial products to every constituents of the society especially the poor or you can say economically backward. RBI have developed the panel for this and implementing it by keeping in mind the main banks. This was done because the burden of financial services to poor people has been made a large prerogative for rural banks and cooperative banks, who are not the mainstream players and therefore mainstream players are not involved in it which leads to many problems. As per many surveys like FITS (Financial Inclusion Tracker Survey) project conducted in India there is high rate of financial inclusion, this concept has been pushed up by government of India and RBI because even after so many years of independence high population of India remain unbanked because high population of India lives in rural area and poor people and they are not literate enough to understand the pros and cons of any specific factor means they don't know what to do and what not to do.

Financial Inclusion program is established by Reserve Bank of India so that all income groups of India can avail the financial services at affordable rates. In many developing countries there are many microfinance institutes whose main focus is on lower income group so that they can work and remove the financial inclusion from developing countries and they can move to their betterment, and become developed countries.

In past 20 years poverty of India has gone down from 55\% to $30 \%$, but still lower income group is $40 \%$ in India. In approximation there are $25 \%$ of people in India who can't afford two times meal in a day and their monthly wages is less than Rs.1500, therefore to improve the welfare of society, RBI establishes Financial Inclusion concept so that lower income group can move to middle income group at least, in these program banks provide individual financial services like they give loans on low interest rate so that they can do their some work. There are many banks who are providing loans to farmer so that they can yield good crops and can sale it and can earn good profit from it.

Each household to have at least one bank account: Banks have been advised to ensure service area bank in rural areas and banks assigned the responsibility in specific wards in urban area to ensure that every household has at least one bank account.

Financial inclusion is a key element in the strategy to achieve inclusive development of a nation. By $\mathbf{P}$. Chidambaram, CRISIL Report

"Overcoming poverty is not a gesture of charity. It is an act of justice. It is the protection of a fundamental human right, the right to dignity and a decent life. While poverty persists, there is no true freedom."- Nelson Mandela

\section{Significance Of Financial Inclusion}

Besides giving access to banking, it also enables government subsidies and social security benefits to be directly credited to the accounts of the beneficiaries, enabling them to draw the money from the bank SAATHI or business correspondents in their village itself.

This initiative enables small and marginal farmers to obtain credit at lower rates from banks and other financial institutions. This would insulate them from exploitation of the money lenders. Government's emphasis on bankers is to take up this task with a sense of responsibility and understanding and exercise courtesy and respect, especially to small borrowers.

The initiative is also important to protect the customers, especially the most vulnerable ones, from harsh financial practices and prevent them from being overburdened by debt. All in all, the end objective should be to empower people to achieve their own goals through enhancing their financial capabilities. 


\section{Model Of Financial Inclusion}

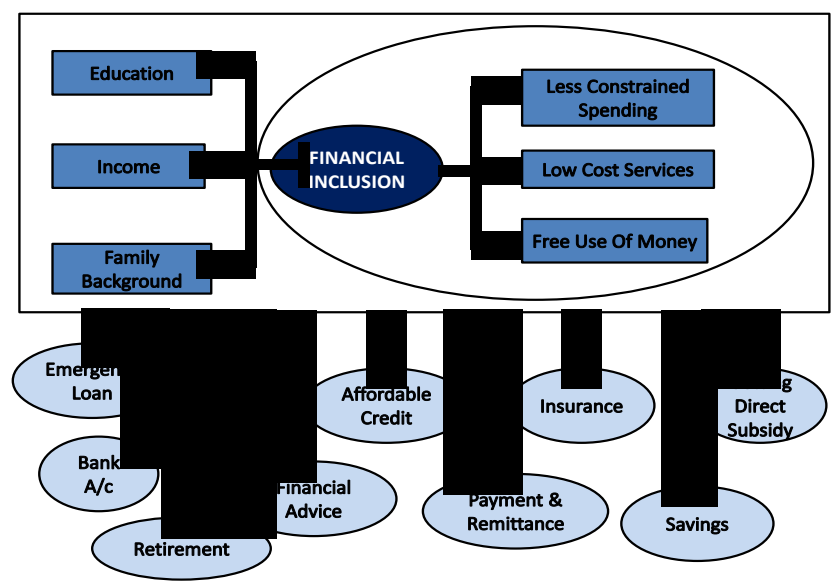

\section{Past Scenario Of Fi In India}

Financial inclusion is certainly not just a recent phenomenon. In India, the earliest effort at financial inclusion can be traced back to 1904, when the co-operative movement began in the country.

In a big nation like India, providing banking facilities across the length and breadth of the country, especially in rural areas, has always been a great challenge for the successive governments since Independence. Even though nationalisation gave a big boost to expansion of banks in rural areas with Public Sector Banks becoming important instruments for advancement of rural banking and changing lives of rural populace.

RBI set up the Khan Commission in 2004 to look into financial inclusion and the recommendations of the commission were incorporated into the mid-term review of the policy (2005-06). In the report RBI exhorted the banks with a view to achieving greater financial inclusion to make available a basic "no-frills" banking account.

The period 1969 to 1991 is witness of a huge increase in the branch outreach in India as the average population covered by a bank branch fell from 64,000 to 13,711. In 1991 along with reforms for liberalising and opening the economy, financial sector reform aimed at deregulation, increased competition and strengthening the banking sector through recapitalisation and adoption of prudential measures. The Indian banking industry today is quite robust and strong to be able to take on the challenges of achieving greater financial inclusion.

In the Annual Policy of the Reserve Bank for 2004-05, the Governor, Dr. Reddy observed and I quote "There has been expansion, greater competition and diversification of ownership of banks leading to both enhanced efficiency and systemic resilience in the banking sector. However, there are legitimate concerns in regard to the banking practices that tend to exclude rather than attract vast sections of population, in particular pensioners, self-employed and those employed in unorganised sector".

RBI introduced a three-year financial inclusion programme in April 2010 that witnessed banks opening outlets in 200,000 villages. The banking regulator has asked banks to draw up a financial inclusion plan for 2013-2016 to broaden access. According to the panel, by 1 January 2016, each low-income household and small business would have "convenient" access to providers that have the ability to offer them "suitable" investment and deposit products, and pay "reasonable" charges for their services.

'SWABHIMAAN' - a financial security program was launched jointly by the Central Government and the Indian Banks' Association (IBA) to ensure banking facilities in habitation with a population in excess of 2000 by March 2012. This nationwide program on financial inclusion was launched in February, 2011 with its focus on bringing the deprived sections of the society in the banking network to ensure that the benefits of economic growth reach everyone at all levels. Through this program government is making effort to transform rural India through financial inclusion.

The Financial Education Campaign provided complimentary resources to organizations with a desire to share financial education information with those they serve. Qualified organizations receive the training and resources they need to deliver a comprehensive financial education program.

RBI governor Raghuram Rajan announced the setting up of the Mor panel in September 2013 to study various aspects of financial inclusion, including institutional frameworks and regulations and a comprehensive monitoring framework to track the progress of the financial inclusion of small businesses and low-income households in India. 
Table-1_Financial Inclusion status in India

\begin{tabular}{|l|c|c|}
\hline & As per Census 2001 & As per Census 2011 \\
\hline Households & $\begin{array}{c}\text { Percentage of households } \\
\text { Availing banking services }\end{array}$ & $\begin{array}{c}\text { Percentage of households } \\
\text { Availing banking services }\end{array}$ \\
\hline Rural & 30.1 & 54.4 \\
\hline Urban & 49.5 & 67.8 \\
\hline Total & 35.5 & 58.7 \\
\hline
\end{tabular}

Source: Rangarajan (2008)

Table-2 Coverage of Banking Services (Ratio of Demand Deposit Accounts to the adult population)

\begin{tabular}{|c|c|c|c|c|}
\hline Region/State/Union Territory & $\begin{array}{l}\text { Adult } \begin{array}{l}\text { Population } \\
\text { (Above 19 years) }\end{array} \\
\end{array}$ & $\begin{array}{l}\text { Total No. of } \\
\text { accounts }\end{array}$ & $\begin{array}{l}\text { No. of acc. Per } 100 \\
\text { of population }\end{array}$ & $\begin{array}{l}\text { No. of acc. Per } 100 \\
\text { of adult pop. }\end{array}$ \\
\hline NORTHERN REGION & 67822312 & 56631826 & 43 & 84 \\
\hline Haryana & 11308025 & 8604132 & 41 & 76 \\
\hline Jammu \& Kashmir & 5379594 & 3372319 & 33 & 63 \\
\hline Punjab & 14185190 & 14898338 & 61 & 105 \\
\hline Rajasthan & 28473743 & 12828959 & 23 & 45 \\
\hline Delhi & 7929589 & 13152895 & 95 & 166 \\
\hline NORTH-EASTERN REGION & 19708982 & 7367684 & 19 & 37 \\
\hline Arunachal Pradesh & 544582 & 219611 & 20 & 40 \\
\hline Assam & 14074393 & 5449787 & 20 & 39 \\
\hline Manipur & 1222107 & 213107 & 9 & 17 \\
\hline Meghalaya & 1088165 & 483084 & 21 & 44 \\
\hline EASTERN REGION & 122136133 & 49690359 & 22 & 41 \\
\hline Bihar & 40934170 & 13689753 & 17 & 33 \\
\hline Jharkhand & 13737485 & 6000348 & 22 & 44 \\
\hline Orissa & 21065404 & 7258164 & 20 & 34 \\
\hline Sikkim & 288500 & 129462 & 24 & 45 \\
\hline West Bengal & 45896914 & 22487486 & 28 & 49 \\
\hline Andaman \& Nicobar Islands & 213660 & 125146 & 35 & 59 \\
\hline CENTRAL REGION & 129316677 & 66456406 & 26 & 51 \\
\hline Chhattisgarh & 11209425 & 3538965 & 17 & 32 \\
\hline Madhya Pradesh & 31404990 & 12285299 & 20 & 39 \\
\hline Uttar Pradesh & 82229748 & 47128859 & 28 & 57 \\
\hline SOUTHERN REGION & 135574225 & 88052912 & 39 & 65 \\
\hline Andhra Pradesh & 44231918 & 25130985 & 33 & 57 \\
\hline Karnataka & 30623289 & 20234481 & 38 & 66 \\
\hline Kerala & 20560323 & 18269788 & 57 & 89 \\
\hline Tamil Nadu & 39511038 & 23839326 & 38 & 60 \\
\hline Lakshadweep & 33686 & 23488 & 39 & 70 \\
\hline Pondicherry & 613971 & 554844 & 57 & 90 \\
\hline ALL-INDIA & 541031553 & 320902390 & 31 & 59 \\
\hline
\end{tabular}

Source: Leeladhar (2005)

Mumbai: A panel of Reserve Bank of India (RBI) has recommended that a special category of banks, called payments banks, be set up to widen the spread of payment services and deposit products to small businesses and low-income households in Asia's third-largest economy, where about $40 \%$ of the population still do not have access to formal financial services.

Such banks will have a minimum entry capital requirement of Rs. 50 crore, one-tenth of what a fullservice bank requires, since they will have a near-zero risk of default, said the panel headed by Nachiket Mor, a member of RBI's central board. Payments banks will be required to comply with all RBI guidelines relevant for commercial banks.

The Mor panel has also proposed the creation of a universal electronic bank account (UEBA) for all adult Indian citizens and access to formal credit for low-income households and small businesses by January 
2016 and major changes in priority sector lending norms, among other things. The country should have enough number and distribution of electronic payment access points so that "every single resident would be within a 15 minute walking distance from such a point anywhere in the country" by January 2016, the panel said.

To enable non-banking financial companies (NBFCs) to become more active in spreading financial inclusion, the Mor panel has recommended a partial convergence of norms for NBFC and banks with regard to bad loan norms. Besides, the panel has proposed to restore the permission of non-deposit taking NBFCs to act as business correspondents of a bank.

The Mor panel has also proposed the creation of a universal electronic bank account (UEBA) for all adult Indian citizens and access to formal credit for low-income households and small businesses by January 2016 and major changes in priority sector lending norms, among other things.

Some experts say that existing institutions such as GRAMEEN banks can be used effectively to expand access to financial services to the poor. India has 57 GRAMEEN banks with more than 17,000 branches across the country. Some other information on FI $\mathrm{i}$ as follow:

1. The Financial Inclusion Taskforce was established by HM Treasury following the publication of 'Promoting financial inclusion' and was formally launched in April 2005.

2. The Taskforce terms of reference cover the three key priority areas identified in 'Promoting financial inclusion': access to banking, affordable credit and free face-to-face money advice.

.3. Following the PAT14 report on access to financial services in 1999, the banking industry worked with the Government to introduce the basic bank account which is specifically designed to address the needs of the financially excluded. In April 2003, the Government began the process of transforming the payment of benefits to direct electronic payment. A significant proportion of benefit recipients were without a bank account and basic bank accounts were expected to meet much of this need. The Post Office Card Account (POCA) was introduced, with a financial contribution from the banks of $£ 182$ million over five years, as a stepping stone into electronic money management.

4. Despite this, the Family Resources Survey indicated that in 2002/03 there were 1.9 million households without a bank account of any kind, containing around 2.8 million adults. In December 2004, the Government and the banks agreed to work together towards the shared goal. The 2002/03 Family Resources Survey data is the baseline for the goal.

\section{It Solutions For Financial Inclusion}

The use of IT solutions for providing banking facilities at doorstep holds the potential for scalability of the FI initiatives. Pilot projects have been initiated using smart cards for opening bank accounts with bio metric identification.

On June 25, 2013, CRISIL India's leading credit rating and Research Company launched an index to measure the status of financial inclusion in India. CRISIL Inclusive is a one-of-its-kind tool to measure the extent of inclusion in India, right down to each of the 632 districts. CRISIL Inclusive is a relative index on a scale of 0 to 100 , and combines three critical parameters of basic banking services - branch penetration, deposit penetration, and credit penetration - into one metric.

- The all-India CRISIL Inclusive score of 40.1 is low, though there are clear signs of progress - this score has improved from 35.4 in 2009.

- Deposit penetration is the key driver of financial inclusion - the number of savings accounts (624 million), is almost four times the number of loan accounts (160 million).

- 618 out of 632 districts reported an improvement in their scores during 2009-2011.

- The top three states and Union Territories are Puducherry, Chandigarh, and Kerala; the top three districts are Pathanamthitta (Kerala), Karaikal (Puducherry), and Thiruvananthapuram (Kerala).

Table-3 Financial Inclusion Index by CRISIL

\begin{tabular}{|c|c|c|c|}
\hline Region & Inclusion 2011 & Inclusion 2010 & Inclusion 2009 \\
\hline India & 40.1 & 37.6 & 35.4 \\
\hline Southern Region & 62.2 & 58.8 & 54.9 \\
\hline Western Region & 38.2 & 35.8 & 33.9 \\
\hline Northern Region & 37.1 & 34.8 & 33.3 \\
\hline Eastern Region & 28.6 & 26.3 & 24.3 \\
\hline North-eastern Region & 28.5 & 26.5 & 23.8 \\
\hline
\end{tabular}

Source: Crisil Inclusix (2013)

CRISIL Inclusix scores for 618 districts (of the total 632 districts in India) improved in 2011 from their 2009 levels. 
Chart-1 Banking Industry Financial Inclusion

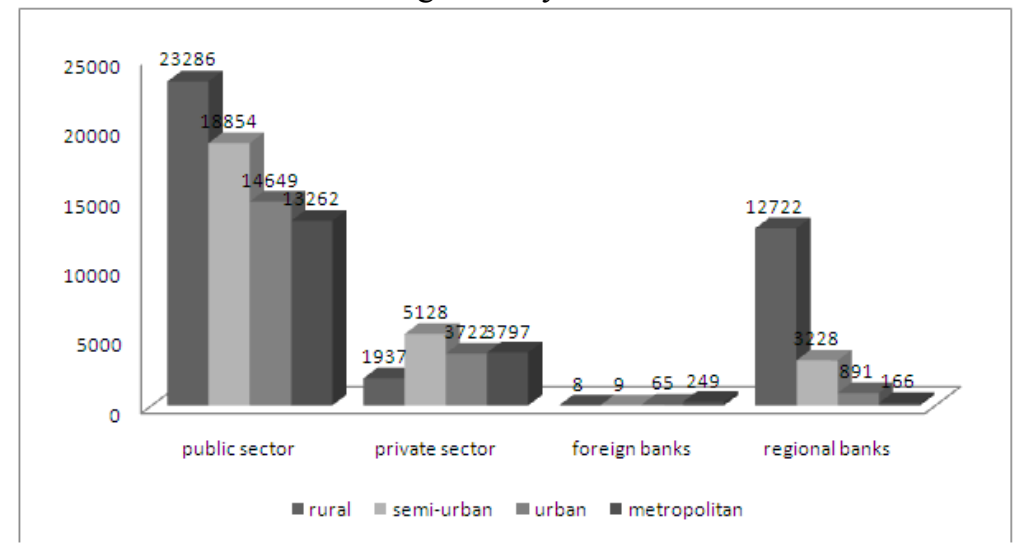

Source: Rangarajan (2008)

Chart-2_Overall Progress in Banking in Urban and Rural Areas in Last 4 Years

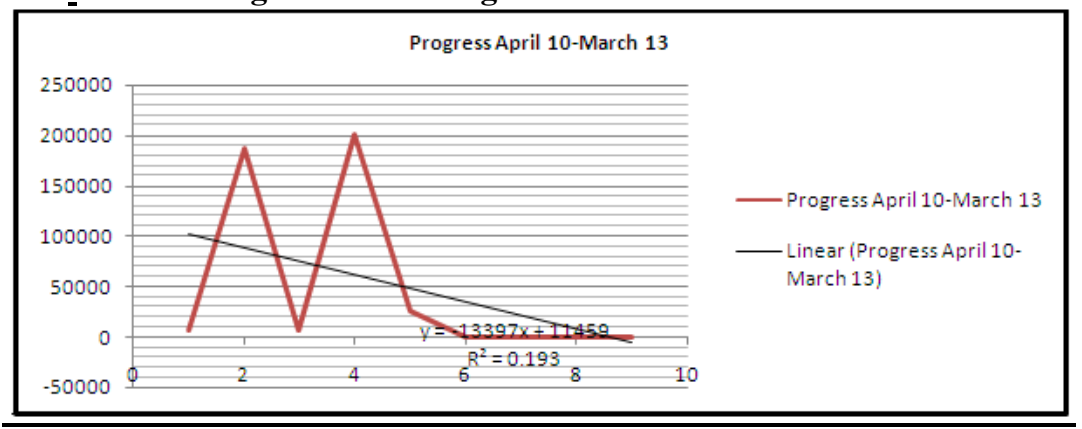

Source: Rangarajan (2008)

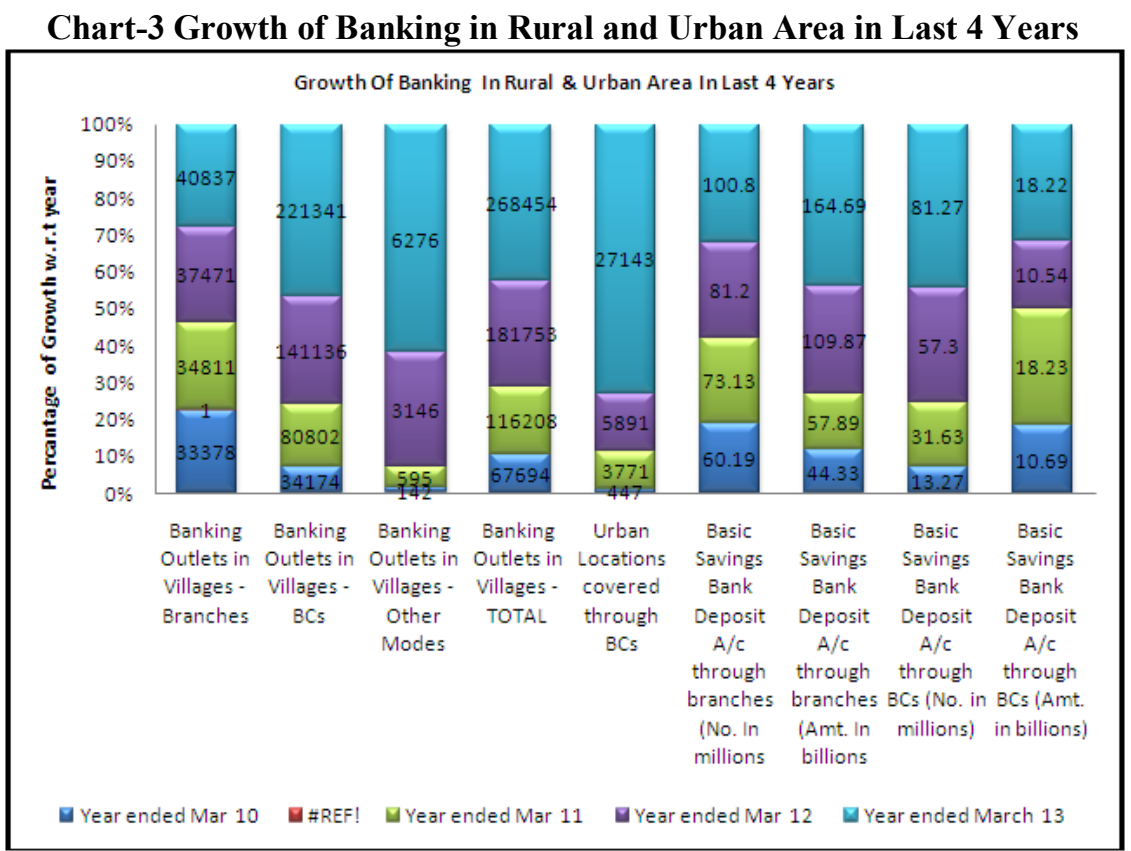

Source: Rangarajan (2008)

\section{Conclusion}

The financial system in India has grown rapidly in the last three decades and more. The functional and geographical coverage of the system is truly impressive. Nevertheless, data do show that there is exclusion and that poorer sections of the society have not been able to access adequately financial services from the organized financial system. There is an imperative need to modify the credit and financial services delivery system to achieve greater inclusion. There is a long way to modify particularly the credit delivery system of the banks and 
other related institutions to meet the credit requirements of marginal and sub-marginal farmers in the rural areas in a fuller measure. However, creating an appropriate credit delivery system is only a necessary condition. This needs to be supplemented by efforts to improve the productivity of small and marginal farmers and other entrepreneurs so that the credit made available can be productively employed. While banks and other financial institutions can also take some efforts on their own to improve the absorptive capacity of the clients, it is equally important for Government at various levels to initiate actions to enhance the earnings capacity of the poorer sections of the society. The two together can bring about the desired change of greater inclusion quickly.

\section{References}

[1]. Chakrabarty K.C (2013), 'Financial Inclusion in India:Journey So Far And the Way Forward', Key note addressat Finance Inclusi on Conclave Organised by CNBC TV18 at New Delhi.

[2]. Crisil Inclusix (2013) a Report on Index to Measure India's Progres on Financial Inclusion, June 2013. P-14. Accessed on $1^{\text {st }}$ march 2014 from http://crisil.com/pdf/corporate/CRISIL-Inclusix.pdf.

[3]. Leeladhar V(2005), 'Taking Banking Services to the Common Man - Financial Inclusion', Commemorative Lecture at the FedbankHormis Memorial Foundation at Ernakulam.

[4]. Mittal, Satish K (2008) Corporate Restructuring: A Strategic Decision, Journal of Strategic Innovators, May-July 2008, Volume 1, Issue 4, pp-64-67.

[5]. Mittal, Satish K and Bansal, Lalit K (2008) The Impact of mergers and Acquisitions on Corporate Performance in India, Journal of Management Decision, Vol. 46, No.10, 2008, PP-1531-1543.

[6]. Mittal, Satish K and Gupta, Ishant (2013) Mergers and Acquisitions: As Review and Research Agenda, International Journal of Research and Development in Technology and Management, Vol. 19, Issue 25. Pp-1-15.

[7]. Mittal, Satish K and Shrivastava, Deepa (2012) A Study Of The Various Dimensions In The Area Of Mergers And Acquisitions, Journal of Advanced Research in Organizational Psychology, Vol-1, Issue-1, 2012, pp-31-43.

[8]. Mittal, S. K. (2013). Mergers and Acquisitions as Strategy: Texts \& Cases. Mergers and Acquisitions as Strategy: Texts \& Cases, 1, 253.

[9]. Planning Commission. Government of India (2009): "Broadening Access to Finance"(Chapter - 3) in A Hundred Small Steps: Report of the Committee on Financial Sector Reforms.

[10]. Rangarajan, C (2008) "Report of the Committee on Financial Inclusion", Ministry of Finance, Government of India, 2008.

[11]. Sarkar A.N (2013), 'Financial Inclusion Part-II: Fostering Sustainable Economic Growth in India', The Banker, Vol. VIII, No.5, pp.32-40. 